\title{
Medievalista
}

Online

$30 \mid 2021$

Número 30

o texto e os contextos em debate

\section{Nos 800 anos das Inquirições régias de 1220}

o texto e os contextos em debate

In the 800 years of the Royal Inquisitions of 1220: the text and contexts under

discussion

\section{Filipa Roldão}

\section{(2) OpenEdition}

\section{Journals}

Edição electrónica

URL: https://journals.openedition.org/medievalista/4630

ISSN: 1646-740X

\section{Editora}

Instituto de Estudos Medievais - FCSH-UNL

\section{Refêrencia eletrónica}

Filipa Roldão, «Nos 800 anos das Inquirições régias de 1220», Medievalista [Online], 30 | 2021, posto online no dia 01 julho 2021, consultado o 24 julho 2021. URL: http://journals.openedition.org/ medievalista/4630

Este documento foi criado de forma automática no dia 24 julho 2021.

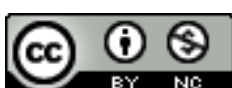

Mediavalista está licenciado com uma Licença Creative Commons - Atribuição-NãoComercial 4.0 Internacional. 


\section{o texto e os contextos em debate}

\section{Nos 800 anos das Inquirições régias de 1220}

o texto e os contextos em debate

In the 800 years of the Royal Inquisitions of 1220: the text and contexts under

discussion

Filipa Roldão

\section{NOTA DO EDITOR}

Data recepção do artigo / Received for publication: 17 de Março de 2021

1 No ano de 2020, assinalaram-se os 800 anos das inquirições gerais ordenadas por D. Afonso II, rei de Portugal, acontecimento que o Instituto de Estudos Medievais (NOVA FCSH), com a parceria do Centro de História da Universidade de Lisboa (CH-ULisboa), decidiu celebrar através de três iniciativas que, no seu conjunto, reafirmam a investigação que esse Instituto tem vindo desde há muito a desenvolver em torno dos inquéritos régios medievais, designadamente através das actividades desenvolvidas pelo projecto Regnum Regis - As inquirições de 1220 e a génese da memória documental do reino medieval português ${ }^{1}$.

Amélia Aguiar Andrade (NOVA FCSH-IEM), José Augusto Sotomayor-Pizarro (ACL; FLUPCEPESE), Filipa Roldão (CH-ULisboa) e João Luís Fontes (NOVA FCSH-IEM) coordenaram a organização do colóquio internacional Inquirições e poder na Europa medieval (séc. XIIXIV). Nos 800 anos das inquirições do rei Afonso II de Portugal, que teve lugar na Academia das Ciências de Lisboa e no Arquivo Nacional / Torre do Tombo, nos dias 19 e 20 de Outubro de 2020. Com o objectivo amplo de actualizar linhas de reflexão sobre a natureza, os agentes, os territórios e os contextos de produção dos inquéritos régios no Ocidente medieval, o colóquio aprofundou o estudo do caso português, sobretudo em 
torno de 1220, promovendo um debate comparativo, através de contributos internacionais diversos e geograficamente representativos.

3 Numa primeira parte, exclusivamente dedicada ao Ocidente europeu, David Roffe apresentou linhas de reflexão em torno do caso inglês e do Domesday Book, Thierry Pécout dedicou-se aos inquéritos gerais angevinos, Marie Dejoux ensaiou uma abordagem comparativa entre o caso francês e o caso português, Eloisa Ramirez Vaquero abordou o caso de Navarra e Stanislav Bárta o, para nós, pouco conhecido caso checo. Seguidamente, o colóquio centrou-se no caso português, com uma reflexão sobre as inquirições medievais portuguesas de modo cronologicamente amplo, como o comprovam os contributos de Maria João Branco sobre o papel das inquirições nos processos judiciais envolvendo a Igreja nos séculos XII e XIII, os de José Augusto Sotomayor-Pizarro sobre o papel da Academia das Ciências de Lisboa na edição das inquirições medievais e sobre a política régia no lançamento das inquirições dionisinas, e, ainda, o de Bernardo Vasconcelos e Sousa sobre dimensões do poder régio nas inquirições de D. Afonso IV. Por fim, um conjunto de reflexões procurou reinterpretar as inquirições do ano de 1220, sob renovadas perspectivas. Hermínia Vasconcelos Vilar dedicou-se à conjuntura política antecedente, enquanto Amélia Aguiar Andrade se centrou na releitura do território abrangido pelo inquérito de 1220 . Filipa Roldão e Joana Serafim propuseram uma reflexão sobre os manuscritos preservados do inquérito e a sua genealogia, Mário Jorge Barroca e Sérgio Guedes procuraram alcançar novas pistas para o conhecimento da organização militar portuguesa, e João Luís Fontes e Maria Filomena Andrade dedicaram-se à compreensão da inserção monásticoconventual no Entre Douro e Minho.

O presente colóquio viria ainda a ser o lugar escolhido para o lançamento de um selo comemorativo dos 800 anos das inquirições de 1220, numa parceria editorial entre os CTT e José Augusto Sotomayor-Pizarro.

5 O encerramento dos trabalhos consagrou a segunda das iniciativas comemorativas em torno das inquirições de 1220: a abertura da mostra documental subordinada ao tema Dominus Rex. As Inquirições Medievais dos Reis de Portugal , patente no Arquivo Nacional da Torre do Tombo, entre os dias 20 de Outubro de 2020 e

19 de Janeiro de 2021. Em estreita relação com a reflexão proposta no colóquio, esta mostra procurou conduzir o visitante pelos manuscritos que albergam o texto das principais inquirições régias medievais, conservados no Arquivo Nacional da Torre do Tombo, assim como por um conjunto de selos régios que testemunham a afirmação do poder dos monarcas portugueses. $O$ catálogo desta mostra, em edição bilingue português/inglês e em acesso aberto, é coordenado pelos organizadores do colóquio, os quais, juntamente com Miguel Metelo Seixas, assinam pequenos textos de apresentação e reinterpretação das peças expostas 2.

6 A terceira e última iniciativa consiste na reedição do texto dos manuscritos que compõem as inquirições de 1220 , tomando como ponto de partida, por um lado, a edição oitocentista de Alexandre Herculano e, por outro, os contributos dados pelo projecto Regnum Regis. Amélia Aguiar Andrade, João Luís Fontes, Filipa Roldão e Joana Serafim serão os editores da obra que integrará um novo volume da nova série Inquisitiones dos Portugaliae Monumenta Historica, com a chancela da Academia das Ciências de Lisboa, e com data de publicação prevista para o presente ano de 2021. 
7 As iniciativas científicas de comemoração dos 800 anos passados sobre o inquérito de 1220 procuraram, pois, uma reavaliação do seu texto e dos seus contextos, reafirmando junto de medievalistas e do público em geral o valor histórico de um dos patrimónios documentais mais antigos do país.

\section{NOTAS}

1. Resultados disponíveis em https://iem.fcsh.unl.pt/section.aspx?kind=outros\&id=258.

2. ANDADE, Amélia Aguiar; FONTES, João Luís; SOTTOMAYOR-PIZARRO, José Augusto de (Ed.) -

Dominus Rex. As Inquirições Medievais dos Reis de Portugal. Catálogo da mostra documental

Dominus Rex. The Medieval Inquiries of the Kings of Portugal: Catalogue of the Documental Exhibition.

Lisboa: Instituto de Estudos Medievais/Centro de História da Universidade de Lisboa, 2020. Disponível in https://repositorio.ul.pt/handle/10451/44861; e, https://run.unl.pt/handle/ 10362/107600? mode=full. 